\title{
PERINGKATAN KEMAMPUAN BERBICARA MENGGUNAKAN METODE BERMAIN DRAMA DI KELAS IV SDN 2 DUWET KECAMATAN PANARUKAN
}

\author{
Aenor Rofek $^{1)}$ Mory Victor Febrianto ${ }^{2)}$ \\ gonzalesrofik99@gmail.com \\ Universitas Abdurachman Saleh Situbondo
}

\begin{abstract}
Speaking skills are skills for expressing ideas, thoughts, and feelings verbally. Speaking is a form of communication that shapes human behavior that utilizes physical factors, namely utterances, in the form of sounds, body movements, expressions to reinforce the content of speech. Based on preliminary observations done on April 23, 2018 at SDN 2 Duwet, as many as 33 students could not communicate well; they were shy in expressing opinions in discussion forums. They were also unable to asnwer questions given by the teacher. In this study, the researchers tried to overcome these problems by implementing drama method. In cycle one (1) there was an increase in students' speaking skills by 30\%,, while in the second cycle (2) there was a $40 \%$ increase. Thus, it can be concluded that the use of the drama method is able to improve speaking skills of the fourth grade students.
\end{abstract}

Keyword : talking, drama, and methods.

\section{PENDAHULUAN}

Bahasa sebagai alat komunikasi mempunyai peranan penting dalam kehidupan manusia. Dengan bahasa, komunikasi antara penutur dan pendengarnya dapat berlangsung dengan baik sehingga informasi yang disampaikan penutur dapat ditanggapi atau diberi reaksi oleh penerima tuturan.

Keterampilan berbicara adalah keterampilan untuk mengungkapkan gagasan, pikiran, dan perasaan secara lisan. Berbicara adalah bentuk komunikasi yang membentuk perilaku manusia yang memanfaatkan faktor fisik, yaitu alat ucap, berupa suara, gerakan tubuh, mimik untuk mempertegas isi pembicaraan. Arsjad dan Mukti (1988:170) menyatakan, untuk menjadi pembicara yang baik, seorang pembicara selain harus memberikan kesan bahwa ia menguasai masalah yang dibicarakan, si pembicara juga harus memperlihatkan keberanian dan kegairahan. Pembicara yang tidak gugup dan bergairah dalam berbicara merupakan modal utama untuk berbicara.

Faktor yang harus dipenuhi untuk penunjang keefektifan bercerita adalah faktor kebahasaan dan non kebahasaan. Seorang pencerita yang baik harus memperhatikan 1) ketepatan ucapan, 2) penempatan tekanan nada, sendi, dan 
ritme sesuai, 3) pilihan kata yang tepat, jelas, dan bervarisi, dan 4) ketepatan sasaran pembicaraan. Faktor nonkebahasaan yaitu berkaitan perilaku tingkah laku bercerita yaitu 1) sikap wajar tenang, dan tidak kaku, 2) pandangan harus diarahkan kepada lawan bicara, 3) ketersediaan menghargai pendapat orang lain, 4) gerak-gerik dan mimik yang tepat, 5) kenyaringan suara, 6) kelancaran, 7) relevansi atau penalaran, 8) dan penguasaan topik (Arsjad dan Mukti,1988:17). Faktor kebahasaan dan non kebahasaan akan meningkatkan nilai tinggi seorang pencerita. Seseorang yang bercerita dengan memperhatikan keefektifan bercerita yaitu faktor kebahasaan dan non kebahasaan akan dapat menyampaikan informasi dengan efektif. Siswa SD di kehidupan sehari-hari senang bercerita dan berbicara dengan teman- teman, dan orang yang ada di sekitarnya. Berdasarkan pengamatan siswa SD terlihat Aktif senang bercerita dalam keadaan santai dan terjadi spontanitas. Akan tetapi, apabila ada kegiatan diskusi seringkali Siswa tidak bisa mengungkapkan apa yang ada dipikirannya, sering kali grogi dalam presentasi, masih ragu dalam menjawab pertanyaan.

Berdasarkan observasi awal pada tanggal 23 April di kelas 4 di SDN 2 Duwet yaitu sebanyak 33 Siswa, sebanyak 75 persen siswa masih belum bisa berkomunikasi didepan kelas secara baik, mereka masih malu-malu dalam mengutarakan pendapat ketika ada forum diskusi maupun ketika ada pertanyaan dari guru masih belum menjawab. Pada kegiatan pembelajaran mata pelajaran Bahasa Indonesia yaitu mencari Unsur-Unsur Intrinsik dalam cerita anak-anak dilatih untuk bisa memahami unsur intrinsik dengan cara kegiatan belajar berkelompok. Dari kegiatan kelompok tersebut Siswa harus mengungkapkan temuan- temuan yang ada dicerita secara lisan. Pada saat diskusi banyak siswa masih ragu dan ada juga yang masih terbata-bata dalam menyusun kalimat. Dalam hal ini, seharusnya siswa masih belum berani berbicara di depan teman-temannya.

Berdasarkan permasalahan di atas, perlu adanya pembenahan suatu proses pembelajaran yang dapat menimbulkan ketertarikan siswa dalam berbicara pada guru dan teman-temannya. Permasalahan keterampilan berbicara kelas IV SDN 2 Duwet ini dapat diatasi dengan Pembelajaran drama, pembelajaran Drama tidak hanya dibelajarkan tentang bagaimana seseorang dapat bermain drama melainkan 
juga mampu meningkatkan kemampuan berbicara secara baik. Kompetensi berbicara sebagai salah satu kompetensi berbahasa produktif yang terdapat di dalam materi drama, kurang mendapat pengelolaan yang tepat dalam pembelajaran. Pembelajaran drama selalu saja hanya mengasah keterampilan membaca dan menulis peserta didik, tetapi justru membelenggu kreativitas peserta didik karena terlalu banyak materi hafalan dan teoritis. Seiring waktu, hal ini mulai disadari bahwa metode ceramah tidak bisa dijadikan pedoman untuk mengajar drama. Pembelajaran drama mempunyai peran yang cukup penting untuk melatih peserta didik mengasah kemampuan berekspresi dalam bidang seni. Terlebih lagi dalam aspek memerankan suatu tokoh drama, dengan kemampuan memerankan tokoh drama, Siswa dapat melatih kemampuan berbicara dengan cara memerankan berbagai karakter dalam drama tersebut cara ini sangat ampuh untuk mengatasi kemampuan berbicara yang masih rendah bagi anak SD.

Penelitian ini bertujuan untuk memperbaiki kemampuan berbicara siswa di depan teman-temannya sehingga pembelajaran dapat berjalan dengan maksimal dikarenakan adanya timbal balik dari semua peserta didik. Penelitian pendidikan atau yang populer disebut PTK adalah upaya untuk memperbaiki hasil belajar dengan menggunakan berbagai strategi. Pada penelitian ini dicoba penggunaan strategi dengan metode bermain drama.

\section{METODE PENELITIAN}

\section{Tempat Penelitian}

Penelitian ini dilakukan di kelas IV SDN 2 Duwet Kec.Panarukan terdiri dari 33 siswa. Guru kelas IV adalah Joko Sudiono, S.Pd. Pemilihan tempat berdasarkan pada rendahnya keterampilan berbicara khususnya pada siswa kelas IV SDN 2 Duwet. Selain itu, pemilihan tempat didasarkan adanya hubungan baik antara peneliti dan Guru Kelas IV sehingga terjadi kerjasama yang baik.

\section{Waktu Penelitian}

Penelitian tindakan kelas ini dilaksanakan pada bulan April sampai Mei tahun 2018 yang meliputi perencanaan dan pelaksanaan tindakan. Adapun pelaksanaan tindakan disesuaikan dengan jadwal kelas IV SDN 2 Duwet, yakni 
hari Senin pukul 10.00-11.00 dan hari Rabu pukul 10.00 - 11.00.

\section{Jenis Penelitian}

Rancangan penelitian dalam penelitian ini menggunakan penelitian tindakan kelas. Hakikat penelitian tindakan kelas atau class room action research terletak pada adanya tindakan dalam situasi yang alami untuk memecahkan permasalahan-permasalahan praktis atau meningkatkan kualitas praktik.

Tindakan tersebut berupa pemberian solusi yang tepat dalam memecahkan masalah kurangnya kemampuan membaca siswa dengan menggunakan pembelajaran keterampilan bermain drama. Kegiatan penelitian ini dilaksanakan dalam satu tahap. Kegiatan diawali dengan pengamatan awal untuk mendapatkan data awal atau mengetahui kenyataan di lapangan dan melakukan diagnostik dari hasil pengamatan. Setelah tahap pengamatan awal peneliti melakukan perencanaan untuk tahap pembelajaran.

Pada tahap ini dibagi menjadi dua pertemuan. Pertemuan pertama berlangsung atas dasar diagnostik yang diperoleh melalui pengamatan awal yang dilakukan peneliti terhadap hasil belajar siswa dalam pembelajaran memahami struktur drama dengan penayangan video- audio tentang drama. Pada pertemuan ke dua peneliti memberikan materi drama dan mulai memberikan contoh adegan atau lakon dalam drama.

\section{(a) Perencanaan}

Alternatif tindakan perbaikan pembelajaran dapat diwujudkan dalam bentuk hipotesis tindakan. Hipotesis tindakan mengindikasikan dugaan mengenai perubahan dalam arti perbaikan yang akan terjadi apabila suatu tindakan dilakukan. Rencana tindakan yang akan dilakukan pada penelitian ini adalah dengan meyusun rancangan tindakan peningkatan kemampuan bermain drama pembelajaran melalui kegiatan berikut.

a) menyusun rancangan tindakan berupa model satuan pelajaran atau rancangan pembelajaran: hal yang menjadi fokus perhatian meliputi perumusan tujuan pembelajaran, kegiatan pembelajaran, dan evaluasi, menyiasati pembelajaran dengan cara menyiapkan sarana dan prasarana pendukung proses pembelajaran, dan 
b) menyusun alat perekam data meliputi: pedoman untuk melakukan observasi, pedoman wawancara, dan pedoman penilaian analisis bermain drama.

\section{(b) Pelaksanaan/Tindakan}

Tindakan yang dilakukan peneliti sebagai upaya untuk perbaikan, peningkatan, maupun perubahan yang diinginkan. Apabila persiapan tindakan telah siap, maka skenario pembelajaran yang telah direncanakan dilaksanakan dalam situasi yang sebenarnya (faktual).

Kegiatan pelaksanaan tindakan merupakan tindakan pokok dalam siklus penelitian tindakan kelas. Pelaksanaan tindakan ini terletak pada saat proses belajar mengajar antara guru dengan siswa, materi, dan strategi yang digunakan dalam pembelajaran. Kegiatan pelaksanaan tindakan yang dilakukan pada tahap ini sebagai berikut:

a) melaksanakan pembelajaran kemampuan bermain drama;

b) mengadakan observasi pada siswa dan Guru saat tindakan dilakukan dengan menggunakan pedoman serta alat yang sudah disiapkan; dan

c) melakukan refleksi terhadap tindakan yang dilakukan; hasil refleksi yang dilakukan dimanfaatkan untuk perbaikan, penyempurnaan pembelajaran bermain drama siswa selanjutnya.

\section{Seting dan Subjek Penelitian}

Seting penelitian dilaksanakan di SDN 2 Duwet kelas 4. Kegiatan penelitian ini akan dilaksanakan selama 4 x 35 menit meliputi 2 kali pertemuan dengan 1 kali siklus. Subjek dari penelitian ini adalah siswa kelas 4 SDN 2 Duwet, dimana siswa di kelas tersebut memiliki kemampuan berbicara yang masih rendah.

\section{Prosedur Penelitian}

\section{Persiapan Penelitian}

Menurut Kemmis dan McTaggart (dalam Soepono, 2000:1) rancangan penelitian tindakan kelas terdiri dari beberapa tahap kegiatan, meliputi: perencanaan/rancangan, observasi, dan refleksi. Berdasarkan hal tersebut, dapat diuraikan secara rinci langkah- langkah yang digunakan dalam penelitian ini untuk meningkatkan keterampilan bermain drama siswa kelas 4 SDN 2 Duwet 
sebagai berikut.

\section{1) Prasiklus}

Pada tahap prasiklus ini peneliti mengadakan penelitian awal untuk mengetahui situasi yang sebenarnya, seberapa besar kemampuan siswa siswa kelas 4 SDN 2 Duwet dalam materi bermain drama dengan menggunakan metode yang biasa digunakan oleh guru pada waktu mengajar. Selain itu peneliti juga mengadakan observasi terhadap proses pembelajaran bahasa Indonesia.

Dalam pembelajaran memahami struktur cerpen yaitu unsur intrinsik yang dilakukan oleh guru berdasarkan pengamatan peneliti, diketahui bahwa strategi pembelajaran yang digunakan guru kurang sesuai/kurang tepat bila diterapkan materi bahasa Indonesia terutama kemampuan berbicara siswa, karena pada strategi pembelajaran yang dipilih dan digunakan guru membuat siswa menjadi bosan dan monoton dalam proses pembelajaran. Siswa hanya mendengarkan ceramah dari Guru kemudian mengerjakan tugas dan diskusi tanpa adanya latihan berdiskusi sehingga siswa banyak yang tidak bisa berpendapat. Strategi pembelajaran yang dipilih dan digunakan guru dalam pembelajaran dan pola ajar ini bisa saja mempengaruhi kemampuan berbicara siswa.

\section{Pelaksanaan Penelitian}

Pelaksanaan penelitian akan dilaksanakan di kelas 5 dikarenakan ketika proposal ini dibuat siswa sudah hampir kenaikan kelas akan tetapi materi cerpen masih ada di kelas 5. Penelitian ini akan dilaksanakan dengan 1 siklus, dengan dimulai perencanaan, pengamatan, observasi, dan refleksi. jika siklus pertama dianggap masih belum berhasil maka akan diadakan tambahan siklus.

\section{Perencanaan}

Tindakan yang dilakukan peneliti sebagai upaya untuk perbaikan, peningkatan, maupun perubahan yang diinginkan. Apabila persiapan tindakan telah siap, maka skenario pembelajaran yang telah direncanakan dilaksanakan dalam situasi yang sebenarnya (faktual).

Kegiatan pelaksanaan tindakan merupakan tindakan pokok dalam siklus penelitian tindakan kelas. Pelaksanaan tindakan ini terletak pada saat proses belajar mengajar antara dosen dengan Mahasiswa, materi, dan strategi yang 
digunakan dalam pembelajaran. Kegiatan pelaksanaan tindakan yang akan dilakukan pada tahap ini sebagai berikut:

\section{Siklus I}

1. Tahap Perencanaan

Meliputi pembuatan RPP, pementasan drama, serta menyusun alat evaluasi.

2. Tahap Pelaksanaan

\section{Pertemuan Pertama}

Meliputi proses kegiatan belajar mengajar dengan praktek drama. Dengan langkah- langkah pembelajaran sebagai berikut:

a. guru melakukan apersepsi pembelajaran tentang drama.

b. Motivasi siswa dengan cara mengaitkan materi tentang apresiasi karya sastra berbentuk drama dengan kehidupan sehari-hari.

c. Guru memberikan teori tentang drama.

d. Siswa menyimak penjelasan dan contoh teks drama

e. Siswa menyimak video tentang teori drama kemudian menyimak video pagelaran drama.

f. Tes tulis untuk mengetahui pemahaman teori drama.

g. Refleksi:

Guru memberikan hadiah bagi siswa yang mendapatkan nilai tertinggi.

\section{Pertemuan ke dua}

Langkah-langkah pembelajaran pada pertemuan ke dua sebagai berikut:

a. Guru menyampaikan salam dan menyampaikan apersepsi berupa menyampaikan tujuan pembelajaran yang ingin dicapai memotivasi.

b. Siswa tentang pentingnya manfaat pembelajaran drama.

c. Guru membentuk kelompok berdasarkan nomor urut absen dan memberikan nomor tampil kepada tiap kelompok melalui undian

d. Memanggil salah satu nomor, kelompok dengan nomor yang dipanggil maju ke atas pentas untuk bermain peran.

e. Refleksi 
- Guru memberikan komentar serta tanya jawab terhadap penampilan masing- masing kelompok;

- Guru memberikan motivasi kepada siswa;

- Guru memberikan hadiah bagi kelompok terbaik.

\section{f. Revisi}

Hasil dari tes dan observasi yang dilakukan digunakan sebagai dasar pengambilan kesimpulan. Jika pada siklus ini masih banyak siswa yang belum mencapai ketuntasan minimal maka dilanjutkan pada siklus selanjutnya.

\section{Observasi}

Observasi adalah upaya merekam segala peristiwa dan kegiatan yang terjadi selama tindakan perbaikan berlangsung, dengan/tanpa alat bantu. Tujuan observasi adalah untuk dapat menata langkah-langkah perbaikan sehingga menjadi lebih efektif dan efisien (Soepono, 2000:9-10).

Sasaran observasi dalam Penelitian Tindakan Kelas (PTK) dipusatkan pada dua aspek yaitu aspek proses dan aspek tindakan dalam pembelajaran beserta segala peristiwa yang melingkupinya.

Keberhasilan tindakan dari segi proses dikatakan berhasil apabila terlaksana dengan baik sesuai dengan yang direncanakan (rencana pembelajaran), sedangkan dari segi hasil, tindakan dikatakan berhasil apabila sudah mendapat nilai $\geq 75$ atau mencapai ketuntasan belajar.

Apabila kedua aspek tersebut berhasil, maka penggunaan strategi pembelajaran bermain drama dalam peningkatan kemampuan berbicara.

\section{Refleksi}

Kegiatan refleksi dalam Penelitian Tindakan Kelas (PTK) diperlukan untuk menemukan titik-titik rawan, sehingga dapat dilanjutkan dengan mengidentifikasikan serta menetapkan sasaran perbaikan baru, menyusun perencanaan baru, mengimplementasikan tindakan perbaikan (Soepono, 2000:3). Peneliti mempertimbangkan hasil PTK dari berbagai kriteria dan berdasarkan refleksi, peneliti melakukan revisi. Refleksi merupakan pemahaman ulang terhadap pembelajaran yang telah dilakukan. Refleksi diadakan setiap satu 
tindakan berakhir. Refleksi ini berupa evaluasi yang telah dilakukan dan pemunculan saran untuk pembelajaran berikutnya.

\section{HASIL PENELITIAN}

\section{Hasil Penelitian}

Penelitian tindakan kelas yang dilakukan dengan menerapkan metode bermain Drama dalam pembelajaran bermain drama dilakukan secara bertahap. Kegiatan dimulai dengan penyusunan rencana tindakan, dilanjutkan dengan implementasi tindakan, pengamatan, dan refleksi. Hal-hal yang diperoleh sebagai hasil penelitian tindakan kelas akan dipaparkan di bawah ini.

\section{Data awal tentang keterampilan mahasiswa bermain drama}

Data ini berisi tentang awal informasi pengetahuan dan pengalaman siswa dalam bermain drama sebelum dilakukan tindakan. Peneliti melakukan observasi melalui angket yang disebarkan ke siswa. Berikut adalah data yang diperoleh dari angket tersebut. Berdasarkan angket pratindakan di atas dapat diketahui bahwa sebagian besar siswa menyukai pembelajaran Bahasa Indonesia di SD, namun besar tingkat kesukaan mereka dalam mempelajari bahasa Indonesia tidak menjamin mereka suka dalam berbicara di kelas. Sebagian besar siswa menganggap bahwa kegiatan berbicara di depan kelas kurang menyenangkan karena banyak yang grogi atau minder, hal ini menjadi alasan mereka kurang menyukai pembelajaran bahasa Indonesia. Pernyataan tersebut diperkuat dari presentase bahwa sebanyak sebanyak 78,26\% siswa kurang menyukai diskusi, 63\% siswa menyukai pembelajaran bermain drama, dan sebanyak $37 \%$ siswa sangat menyukai pembelajaran bermain drama. Melalui hasil prosentase tersebut, dapat diketahui bahwa tingkat kesukaan siswa kelas IV SDN 2 Duwet dalam kegiatan berbicara di kelas masih cukup rendah.

Rendahnya tingkat kesukaan siswa terhadap kemampuan berbicara disebabkan oleh beberapa alasan. Hal itu dapat dilihat pada angket pernyataan nomor 4, yakni saya pernah bermain drama. Sebanyak 13,04\% menyatakan setuju, $30,43 \%$ menyatakan kurang setuju dan sebanyak 6,52\% siswa menyatakan tidak setuju. Dari data persentase di atas dapat diketahui bahwa siswa kelas IV SDN 2 
Duwet sebagian besar dari mereka belum mempunyai

Kondisi yang seperti itu menuntut guru untuk memberikan pembelajaran yang menarik, kreatif, inovatif dan menyenangkan. Hal semua itu dapat diwujudkan dengan penggunaan media ataupun metode yang tepat sehingga mampu menumbuh kembangkan minat siswa terhadap kemampuan berbicara siswa. Namun motivasi dari dalam diri siswa itu sendiri sangat penting yaitu dengan cara bahwa bermain drama itu sangat berpengaruh terhadap kemampuan berbicara. Pengamatan yang dilakukan oleh peneliti, menunjukkan bahwa proses pembelajaran bermain drama di kelas IV SDN 2 Duwet kurang sesuai dengan harapan peneliti. Sebagian besar siswa masih kurang serius selama mengikuti pembelajaran, siswa masih kurang aktif dalam pembelajaran, siswa kurang berani dalam mengemukakan pendapat dan kurang berani tampil di depan kelas, siswa kurang konsentrasi selama mengikuti pembelajaran dan kurangnya keantusiasan siswa dalam pembelajaran bahasa Indonesia.

\section{Pelaksanaan Tindakan Kelas dalam Pembelajaran Bermain Drama dalam meningkatkan Kemampuan Berbicara Siswa Kelas IV}

Pelaksanaan tindakan kelas dalam pembelajaran bahasa Indonesia dengan menggunakan metode bermain drama berlangsung sebanyak 2 siklus dengan empat tahap pada masing-masing siklus. Tahapan meliputi perencanaan, pelaksanaan tindakan, observasi, dan refleksi. Berikut ini akan dipaparkan hasil penelitian tindakan kelas dalam pembelajaran bahasa Indonesia dengan menggunakan metode bermain drama di kelas IV SDN 2 Duwet yang meliputi siklus I dan siklus II.

\section{Pelaksanaan Tindakan Siklus I Pertemuan Pertama}

\section{Perencanaan}

Kegiatan ini dilaksanakan pada hari Senin, 13 November 2017 di ruang kepala Sekolah SDN 2 Duwet. Peneliti dan guru pengampu mata pelajaran bahasa Indonesia mendiskusikan rancangan tindakan yang akan dilakukan dalam proses penelitian ini. Hal-hal yang didiskusikan antara peneliti dan guru pengampu mata pelajaran bahasa Indonesia dalam proses penelitian pada siklus I, antara lain: (1) peneliti menyamakan persepsi dengan guru mata pelajaran bahasa Indonesia 
mengenai penelitian yang akan dilaksanakan pada siklus 1, (2) peneliti mengusulkan digunakannya metode bermain drama, serta menjelaskan cara penerapannya dalam pembelajaran, (3) peneliti dan guru mata pelajaran bahasa Indonesia merancang RPP untuk siklus 1, (4) guru mata pelajaran bahasa Indonesia dan peneliti menyusun lembar penilaian siswa, yaitu berupa instrumen penilaian proses (instrumen nontes) dan hasil (instrumen tes), (5) menentukan jadwal pelaksanaan tindakan. Kemudian disepakati bahwa pelaksanaan tindakan pada siklus pertama ini akan dilaksanakan pada hari 5 dan 11 mei 2018 masing-masing dengan alokasi waktu dua jam pelajaran (2 x 30 menit).

Tahap perencanaan tindakan silus I pertemuan pertama meliputi kegiatan sebagai berikut:

a. Peneliti bersama guru mata pelajaran bahasa Indonesia merancang skenario pembelajaran bermain drama dengan metode bermain drama. Langkahlangkah pada pertemuan pertama yang akan ditempuh adalah sebagai berikut:

1. Guru dan peneliti memberikan apersepsi berupa motivasi terhadap diri siswa tentang bermain drama dan mengabsen siswa;

2. Guru dan peneliti melakukan tanya jawab dengan siswa seputar drama;

3. Guru dan peneliti memberikan materi tentang drama (pengertian drama, jenisjenis drama, unsur-unsur drama) dan mengaitkannya dengan pementasan drama;

4. Guru dan peneliti memutarkan penayangan pementasan drama lalu menyuruh siswa untuk mengamati dan memahami unsur-unsur yang dalam penayangan pementasan drama tersebut;

5. Guru dan peneliti dengan siswa tanya jawab tentang seputar penayangan pementasan drama yang berkaitan dengan unsur-unsur drama;

6. Guru dan siswa melakukan refleksi terhadapa proses belajar-mengajar yang telah dilakukan.

\section{Pelaksanaan}

Pelaksanaan tindakan siklus I dilaksanakan pada hari senin dan Rabu, 5 dan 11 mei 2018. Sesuai dengan skenario pembelajaran yang tertuang dalam 
Rencana Pelaksanaan Pembelajaran (RPP), pelaksanaan pembelajaran dilakukan oleh Guru kelas IV. Sementara itu peneliti melakukan observasi proses pembelajaran. Urutan pelaksanaan kegiatan pada pertemuan pertama adalah sebagai berikut:

a. Guru melakukan apersepsi pembelajaran tentang drama dan menghadapkan mahasiswa pada permasalahan yang kontekstual. Lalu mengecek ketidak hadiran mahasiswa pada saat pembelajaran berlangsung.

b. Guru memberikan motivasi dengan cara mengaitkan materi tentang apresiasi karya sastra yang berbentuk drama dengan kehidupan sehari-hari.

c. Guru pengampu mata kuliah bahasa indonesia memberikan materi tentang tentang apa saja yang harus dilakukan dalam pembelajaran bermain drama.

d. Guru pengampu mata pelajaran bahasa indonesia mempertontonkan sebuah dokumentasi pementasan berjudul "Malin Kundang". Dengan dipertontonkan dokumentasi pementasan tersebut diharapkan siswa mendapat pengalaman baru, lebih tertarik dan lebih mudah dalam memahami apa saja yang diperlukan dan dipersiapkan dalam bermain drama mulai dari persiapan hingga pementasan.

e. siswa diajak berdiskusi tentang drama dan hal apa saja yang perlu diperhatikan mulai dari persiapan hingga pementasan, termasuk unsur-unsur yang membangung drama (intrinsik dan ekstrinsik).

f. Berdasarkan video yang sudah dilihat, siswa bisa menemukan karakterkarakter dari setiap tokohnya.

g. siswa melakukan pengamatan terhadapa karakter masing-masing temannya untuk mengetahui karakter masing-masing. Yaitu dengan cara mengingat kebiasaan-kebiasaan dan memperagakannya.

h. Guru pengampu mata pelajaran bahasa indonesia Melakukan diskusi dengan siswa dan dosen peneliti

i. Peneliti mengamati keseriusan, keaktifan, keberanian, konsentrasi, dan keantusiasan.

j. Melakukan refleksi bersama siswa dan peneliti

k. Guru memberikan hadiah bagi mahasiswa yang mendapatkan nilai tertinggi. 


\section{Observasi}

Dalam pelaksanaan pembelajaran bermain drama dalam meningkatkan berbicara dikelas IV SDN 2 Duwet menggunakan metode bermain drama, peneliti melakukan pengamatan yang dideskripsikan dalam pedoman pengamatan. peneliti bersama Guru pengampu mata pelajaran bahasa indonesia melakukan pengamatan dan evaluasi terhadap jalannya perlakuan tindakan. Hasil yang diperoleh dari pengamatan dan evaluasi ini dapat dilihat dari aktivitas siswa saat pembelajaran. Hal yang diamati dari situasi belajar siswa adalah keseriusan, keaktivan, keberanian, konsentrasi, dan keantusiasan. Sebagian besar siswa terlihat antusias dan serius memperhatikan penayangan video pementasan drama tersebut.

Setelah itu peneliti meminta siswa untuk pengamati terhadap karakter orang lain (temannya sendiri). Sebagian besar siswa melakukannya dengan konsentrasi,namun ada beberapa yang kurang fokus dan melamun. peneliti meminta mereka untuk memperagakan kebiasaan-kebiasaan yang dilakukan orang tersebut. Kebiasan-kebiasaaan yang diperagakan terkadang menimbulkan gelak tawa. Hal ini akan membantu siswa dalam hal memahami karakter tokoh dalam naskah drama nantinya.

Pada pertemuan pertama siklus I ini, siswa terlihat serius dalam mengikuti pembelajaran bermain drama menggunakan metode bermain drama. Karena siswa diarahkan untuk bisa merasakan dan mengalamai sendiri macam-macam karakter tokoh yang mereka alami. Siswa yang masih kesulitan dalam mengikuti pembelajaran tidak takut untuk bertanya. Dari sini keaktivan mulai tumbuh, siswa mulai mengerti mengenai proses dan persiapan seorang aktor sebelum pementasan drama dalam siklus I ini, karena peneliti telah menjelaskan tentang pentingnya pelatihan akting dalam bermain drama. Berdasarkan pengamatan siswa sangat antusias dan bersemangat dalam mengikuti pembelajaran bermain drama.

\section{Refleksi}

Pembelajaran bahasa Indonesia dalam rangka meningkatkan kemampuan 
berbicara dengan model bermain drama pada siklus I pertemuan I, siswa mendapatkan manfaat. siswa terlihat konsentrasi dalam mengikuti pembelajaran ini. siswa lebih berani berbicara di depan kelas. Sebagian besar siswa mengikuti pembelajaran dengan antusias, walaupun masih ada yang suka melamun dan kurang berani mengemukakan pendapat pada pertama ini.

\section{Pelaksanaan Tindakan Siklus II}

\section{Perencanaan}

Kegiatan perencanaan pembelajaran pada siklus II ini dilaksanakan pada hari sabtu, 11 mei 2018 di ruang kepala Sekolah SDN 2 Duwet. Peneliti dan guru mata pelajaran bahasa Indonesia mendiskusikan rancangan tindakan yang akan dilakukan dalam proses penelitian ini. Hal-hal yang didiskusikan antara peneliti dan guru pengampu mata pelajaran bahasa Indonesia dalam proses penelitian pada siklus I, antara lain: (1) peneliti menyamakan persepsi dengan guru mata pelajaran bahasa Indonesia mengenai penelitian yang akan dilaksanakan pada siklus 1, (2) peneliti mengusulkan digunakannya metode bermain drama, serta menjelaskan cara penerapannya dalam pembelajaran, (3) peneliti dan guru mata pelajaran bahasa Indonesia merancang RPP untuk siklus II, (4) guru mata pelajaran bahasa Indonesia dan peneliti menyusun lembar penilaian siswa, yaitu berupa instrumen penilaian proses (instrumen nontes) dan hasil (instrumen tes), (5) menentukan jadwal pelaksanaan tindakan.

Tahap perencanaan tindakan silus II meliputi kegiatan sebagai berikut:

1. Peneliti bersama guru mata pelajaran bahasa Indonesia merancang skenario pembelajaran bermain drama dengan metode bermain drama. Langkah-langkah pada pertemuan pertama yang akan ditempuh adalah sebagai berikut:

2. Guru dan peneliti memberikan apersepsi berupa motivasi terhadap diri siswa tentang bermain drama dan mengabsen siswa;

3. Guru dan peneliti melakukan tanya jawab dengan siswa seputar drama;

4. Guru dan peneliti memberikan materi tentang drama (pengertian drama, jenisjenis drama, unsur-unsur drama) dan mengaitkannya dengan pementasan drama;

5. Guru dan peneliti memutarkan penayangan pementasan drama lalu menyuruh 
siswa untuk mengamati dan memahami unsur-unsur yang dalam penayangan pementasan drama tersebut;

6. Guru dan peneliti dengan siswa tanya jawab tentang seputar penayangan pementasan drama yang berkaitan dengan unsur-unsur drama;

7. Guru dan siswa melakukan refleksi terhadapa proses belajar-mengajar yang telah dilakukan.

\section{Pelaksanaan}

Pelaksanaan tindakan siklus II Sesuai dengan skenario pembelajaran yang tertuang dalam Rencana Pelaksanaan Pembelajaran (RPP), pelaksanaan pembelajaran dilakukan oleh Guru kelas IV. Sementara itu peneliti melakukan observasi proses pembelajaran.

Urutan pelaksanaan kegiatan pada pertemuan pertama adalah sebagai berikut:

1. Guru melakukan apersepsi pembelajaran tentang drama dan menghadapkan mahasiswa pada permasalahan yang kontekstual. Lalu mengecek ketidak hadiran siswa pada saat pembelajaran berlangsung.

2. Guru memberikan motivasi dengan cara mengaitkan materi tentang apresiasi karya sastra yang berbentuk drama dengan kehidupan sehari-hari.

3. Guru pengampu mata pelajaran bahasa indonesia memberikan materi tentang tentang apa saja yang harus dilakukan dalam pembelajaran bermain drama.

4. Guru pengampu mata pelajaran bahasa indonesia mempertontonkan sebuah dokumentasi pementasan berjudul “Ande - Ande lumut”. Dengan dipertontonkan dokumentasi pementasan tersebut diharapkan siswa mendapat pengalaman baru, lebih tertarik dan lebih mudah dalam memahami apa saja yang diperlukan dan dipersiapkan dalam bermain drama mulai dari persiapan hingga pementasan.

5. siswa diajak berdiskusi tentang drama dan hal apa saja yang perlu diperhatikan mulai dari persiapan hingga pementasan, termasuk unsur-unsur yang membangung drama (intrinsik dan ekstrinsik).

6. Berdasarkan video yang sudah dilihat, siswa bisa menemukan karakter-karakter dari setiap tokohnya. 
7. siswa melakukan pengamatan terhadapa karakter masing-masing temannya untuk mengetahui karakter masing-masing. Yaitu dengan cara mengingat kebiasaan- kebiasaan dan memperagakannya.

8. Guru pengampu mata pelajaran bahasa indonesia melakukan diskusi dengan siswa dan dosen peneliti

9. Peneliti mengamati keseriusan, keaktivan, keberanian, konsentrasi, dan keantusiasan.

10.Melakukan refleksi bersama siswa dan peneliti

11.Guru memberikan hadiah bagi siswa yang mendapatkan nilai tertinggi.

\section{Observasi}

Dalam pelaksanaan pembelajaran bermain drama dalam meningkatkan berbicara dikelas IV SDN 2 Duwet menggunakan metode bermain drama, peneliti melakukan pengamatan yang dideskripsikan dalam pedoman pengamatan. peneliti bersama Guru pengampu mata pelajaran bahasa indonesia melakukan pengamatan dan evaluasi terhadap jalannya perlakuan tindakan. Hasil yang diperoleh dari pengamatan dan evaluasi ini dapat dilihat dari aktivitas siswa sudah meningkat lebih besar hal ini dilihat dari kemampuan bermain drama siswa kelas 4 sudah mulai merata yaitu bisa memerankan semua karakter dalam cerita.

Pada pertemuan pertama siklus II ini, siswa terlihat lebih serius dalam mengikuti drama menggunakan metode bermain drama. Karena siswa diarahkan untuk bisa merasakan dan mengalamai sendiri macam-macam karakter tokoh yang mereka alami. Siswa yang masih kesulitan dalam mengikuti pembelajaran tidak takut untuk bertanya. Dari sini keaktifan mulai tumbuh, siswa mulai mengerti mengenai proses dan persiapan seorang aktor sebelum pementasan drama dalam siklus II ini, karena peneliti telah menjelaskan tentang pentingnya pelatihan akting dalam bermain drama. Berdasarkan pengamatan siswa sangat antusias dan bersemangat dalam mengikuti pembelajaran bermain drama.

\section{Refleksi}

Pembelajaran bahasa Indonesia dalam rangka meningkatkan kemampuan berbicara dengan model bermain drama pada siklus II, siswa mendapatkan manfaat. siswa terlihat konsentrasi dalam mengikuti pembelajaran ini. siswa lebih 
berani berbicara di depan kelas. Sebagian besar siswa mengikuti pembelajaran dengan antusias, walaupun masih ada yang suka melamun dan kurang berani mengemukakan pendapat pada pertama ini.

\section{Hasil praktik siswa dalam bermain drama kelas IV}

Hasil praktik siswa dalam kegiatan bermain drama setelah mendapatkan implementasi tindakan sebanyak dua siklus dengan metode bermain drama. Siklus I dalam penelitian dilaksanakan dalam satu kali pertemuan, siswa mengalami peningkatan baik dari segi proses dan hasil yang cukup bagus. Pada siklus II dilaksanakan dalam satu kali pertemuan, keterampilan siswa dalam bermain drama mengalami peningkatan baik dari segi proses dan segi hasil. Hal tersebut dapat dilihat dari tabel proses serta table hasil pembelajaran drama dari sikus I, dan siklus II di bawah ini. Gambar Tabel 2. Daftar Nilai pra siklus kemampuan berbicara siswa dalam pelajaran bahasa Indonesia. 
Tabel 1. Daftar Nilai pra siklus kemampuan berbicara siswa dalam pelajaran bahasa Indonesia.

\begin{tabular}{|c|c|c|c|c|}
\hline No & Nama Siswa & $\begin{array}{c}\text { NILAI } \\
\text { Pra } \\
\text { Siklus }\end{array}$ & $\begin{array}{c}\text { Nilai } \\
\text { Siklus I }\end{array}$ & $\begin{array}{c}\text { Nilai } \\
\text { Siklus } \\
\text { II }\end{array}$ \\
\hline 1 & Abdul Razek & 50 & 55 & 75 \\
\hline 2 & Ainun Noval Ramadani & 70 & 70 & 70 \\
\hline 3 & Aldi Riski Apriliawan & 55 & 60 & 55 \\
\hline 4 & Andika Putra Maulana & 50 & 60 & 50 \\
\hline 5 & Bayu Adi Prayoga & 40 & 50 & 75 \\
\hline 6 & Canda Ayu Kirani & 55 & 70 & 70 \\
\hline 7 & Cianggun Pratiwi & 70 & 70 & 70 \\
\hline 8 & Dwi Agil Bagiharto & 40 & 45 & 77 \\
\hline 9 & Dwi Aji Prasetyo & 57 & 60 & 57 \\
\hline 10 & Fania Putri & 75 & 75 & 75 \\
\hline 11 & Fita Bahri Yuni Ulandari & 60 & 60 & 80 \\
\hline 12 & Fitri Nabilahiz Zhafira & 50 & 75 & 75 \\
\hline 13 & Ivan Nur Wahyudi & 70 & 70 & 70 \\
\hline 14 & Kholisatun Nadifa & 75 & 75 & 75 \\
\hline 15 & Lailatul Hasanah & 55 & 75 & 75 \\
\hline 16 & Lutfiyatus Sholeha & 57 & 60 & 57 \\
\hline 17 & Muhammad Jufri & 75 & 75 & 75 \\
\hline 18 & Muhammad Raihan Bukhori & 60 & 75 & 75 \\
\hline 19 & Muhammad Sainul Bari & 50 & 50 & 75 \\
\hline 20 & Nanda Kurniawan & 57 & 57 & 80 \\
\hline 21 & Nania Safitri & 45 & 50 & 80 \\
\hline 22 & Nur Sulusiya & 55 & 75 & 75 \\
\hline 23 & Reza Novisandi & 50 & 50 & 50 \\
\hline 24 & Ronal Fiansah & 40 & 75 & 75 \\
\hline 25 & Siti Ameliyana Putri & 55 & 60 & 75 \\
\hline 26 & Muhammad Jufri & 57 & 75 & 75 \\
\hline 27 & Syaidila Aries Sandi & 75 & 75 & 75 \\
\hline 28 & Taufiqurrohman & 60 & 60 & 70 \\
\hline 29 & Tegar Maulana Apriliansyah & 50 & 50 & 70 \\
\hline 30 & Ulfa Dwi Amalia & 70 & 70 & 70 \\
\hline 31 & Widya Riskiyani & 57 & 75 & 75 \\
\hline 32 & Wildatussoleha & 45 & 50 & 65 \\
\hline 33 & Yogi Egit Ferdiyansyah & 60 & 60 & 65 \\
\hline
\end{tabular}

Hasil pada pra siklus didapatkan oleh guru dari penilaian hasil belajar 
tentang menceritakan pengalaman diri sendiri di depan kelas. Sedangkan pada siklus I sudah terjadi perubahan yang cukup signifikan dimana dengan bermain drama siswa mulai bisa berbicara di depan umum walaupun dengan media drama.

Pada siklus 1 sudah terlihat perubahan dari keberanian siswa dalam memerankan karakter tokoh dalam drama. Siswa pada siklus ke II juga mengalami perbaikan yang cukup memuaskan dengan KKM sebesar 65 di SDN 2 Duwet terdapat 13 siswa mengalamai peningkatan, maka siswa kelas IV sudah dapat dikatakan sudah mampu berbicara dengan baik dan lancar hal ini dilihat dari nilai siklus II.

Pada siklus II , kegiatan drama dalam hal ini dihubungkan dengan bermain drama bagi siswa kelas IV sudah dikatakan berhasil dikarenakan semua siswa mampu memerankan tokoh dengan sangat baik, sehingga intonasi dan mimik muka juga sudah sesuai karakter dari tokoh yang diperankan.

\section{KESIMPULAN DAN SARAN}

\section{Kesimpulan}

Keterampilan berbicara adalah keterampilan untuk mengekspresikan ide, pikiran, dan perasaan secara lisan. Berbicara adalah bentuk komunikasi yang membentuk perilaku manusia yang memanfaatkan faktor fisik, yaitu alat bicara, dalam bentuk suara, gerakan tubuh, meniru untuk memperkuat isi percakapan. Berdasarkan observasi awal pada bulan Mei 2018 di kelas 4 SDN 2 Duwet yaitu 33 siswa, 75\% siswa masih tidak dapat berkomunikasi di depan kelas dengan baik, mereka masih malu dalam mengungkapkan pendapat mereka ketika ada forum diskusi dan kapan saja pertanyaan dari guru masih belum terjawab. Penelitian ini bertujuan untuk meningkatkan kemampuan berbicara siswa. Sebuah penelitian pendidikan atau populer yang disebut PTK adalah upaya untuk meningkatkan hasil pembelajaran menggunakan berbagai strategi. Dalam penelitian ini, peneliti mencoba menggunakan metode untuk mengatasi masalah tersebut, metode yang dipilih adalah metode drama dalam kegiatan siklus I dan II kegiatan drama, pada siklus satu (1) terdapat peningkatan kemampuan berbicara 
sebesar $30 \%$ yaitu 10 siswa sudah mulai tampil dengan berani di depan kelas. Pada siklus ke dua (2) terjadi peningkatan $40 \%$ yaitu 13 siswa sudah mulai berani tampil. Jadi total peningkatan kemampuan berbicara di kelas sebanyak 23 siswa dari dua siklus tersebut. Pada kegiatan penelitian ini dapat disimpulkan bahwa penggunaan metode drama mampu meningkatkan kemampuan berbicara bagi siswa kelas 4 SD.

\section{Saran}

Berdasarkan penelitian dan pembahasan yang telah dilaksanakan diberikan saran- saran sebagai berikut.

1. Peneliti yang berminat terhadap penelitian PTK, penelitian ini dapat menambah wawasan dan dijadikan sebagai studi banding dalam pembelajaran peningkatan berbicara siswa.

2. Peneliti lain, maka perlu adanya modifikasi strategi dan metode baru dalam mata pelajaran bahasa Indonesia.

\section{DAFTAR PUSTAKA}

Arsjad, Maidar dan Mukti U.S. 1991. Pembinaan Kemampuan Berbicara Bahasa Indonesia.Jakarta : Erlangga.

Endraswara, Suwardi. 2011. Metode Pembelajaran Drama. Yogyakarta: CAPS Morgan, 2006. “Belajar dan Hasil Belajar. Jakarta: Bumi Aksara

Sardiman, 2009. Belajar Merupakan Perubahan Tingkah Laku Atau Penampilan, dengan Serangkaian Kegiatan. Jakarta : Rineka Cipta

Soepono. 2000.Penelitian Tindakan kelas. Yogyakarta: CAPS

Kasihani, Kasbolah E.S. 2001. Penelitian Tindakan Kelas. Malang: Universitas Negeri Malang.

Widayat, Efendi. 2006. Diktat Drama Jawa. Yogyakarta: Fakultas Bahasa dan SeniUniversitas Negeri Yogyakarta. 